\title{
PENGUNGKAPAN CORPORATE GOVERNANCE TERHADAP INDIKASI FRAUD DALAM PELAPORAN KEUANGAN
}

\author{
Pratiwi Nila Sari ${ }^{1}$, Cahyadi Husadha ${ }^{2}$ \\ Program Studi Akuntansi, Fakultas Ekonomi, Universitas Bhayangkara Jakarta Raya, Bekasi ${ }^{1}$ \\ Program Studi Manajemen, Fakultas Ekonomi, Universitas Bhayangkara Jakarta Raya, Bekasi ${ }^{2}$ \\ pratiwi@ubharajaya.ac.id $^{1}, \underline{\text { cahyadi.husadha@dsn.ubharajaya.ac.id }}^{2}$
}

\begin{abstract}
Abstrak
Pada penelitian ini memiliki tujuan yaitu untuk mengetahui pengaruh pengungkapan corporate governance yang meliputi dewan komisaris (BOC), komisaris independen (BOC_IND), komite audit (AC), audit internal (IA) dan KAP big four terhadap indikasi fraud dalam pelaporan keuangan. Populasi pada penelitian ini adalah perusahaan sektor keuangan non bank yang terdaftar di Bursa Efek Indonesia dari tahun 2016-2018. Teknik pengambilan sampel menggunakan purposive sampling sebanyak 108 perusahaan. Metode analisis data menggunakan regresi logistik dengan memperhatikan uji kelayakan model (goodness of fit test) melalui Hosmer and Lameshow test, pengujian model secara simultan yaitu menggunakan Omnibus Test of Model Coefficient, dan uji hipotesis melalui nilai variable in the equation. Hasil penelitian menunjukan bahwa dewan komisaris (BOC) dan KAP big four memiliki pengaruh positif dan signifikan terhadap indikasi fraud dalam pelaporan keuangan. Sedangkan untuk variabel komisaris independen (BOC_IND) memiliki pengaruh negatif dan signifikan terhadap indikasi fraud. Pada variabel komite audit (AC) dan audit internal (IA) tidak memiliki pengaruh terhadap indikasi fraud dalam pelaporan keuangan.
\end{abstract}

Kata Kunci : Corporate Governance, Kecurangan dan Pelaporan Keuangan.

\begin{abstract}
Abctract
In this study, there are objectives intended to discuss corporate governance disclosures given by the board of commissioners (BOC), independent commissioners (BOC_IND), audit committee (AC), internal audit (IA) and the big four KAP for using fraud in finance. The population in this study is non-bank financial sector companies listed on the Indonesia Stock Exchange from 2016-2018. The sampling technique used purposive sampling of 108 companies. The data analysis method uses logistic regression models by taking into account the feasibility test (goodness of fit test) through the Hosmer and Lameshow tests, testing the model simultaneously using the Omnibus Model Coefficient Test, and testing the hypothesis through the variable values in the equation. The results showed the board of commissioners (BOC) and large KAP four had a positive and significant influence on indications of fraud in financial reporting. Whereas the independent commissioner variable (BOC_IND) has a negative and significant effect on fraud indications. The audit committee (AC) and internal audit (IA) variables have no influence on fraud indications in financial reporting.
\end{abstract}

Keywords : corporate governance, fraud and financial reporting.

\section{PENDAHULUAN}

Setiap entitas yang sudah go public wajib mempublikasikan laporan keuangan di Bursa Efek Indonesia sebagai bentuk pertanggungjawaban perusahaan kepada investor dan stakeholders (pemakai laporan keuangan). Laporan keuangan perusahaan yang telah di audit oleh auditor eksternal dapat dijadikan tolok ukur bagi pengguna laporan keuangan. Hasil audit atas laporan keuangan tersebut mempunyai kaitan yang erat dengan industri jasa keuangan khususnya perbankan sebagai pemberi pinjaman atau kreditor, 
khususnya untuk mengambil keputusan kelayakan pemberian pinjaman kepada calon debitur atau perusahaan tersebut.

Namun dalam dunia bisnis seringkali terjadi kecurangan-kecurangan atau tindakan menyimpang dari prosedur atau standar yang sudah ditetapkan. Salah satu bentuk kecurangan pada perusahaan adalah manipulasi atau merekayasa data pada laporan keuangan sehingga mengakibatkan kerugian para stakeholders.

Tindakan fraud hendaknya dapat dideteksi dan dicegah sejak awal, untuk menghindari efek domino akibat hilangnya kredibilitas dan akuntabilitas perusahaan yang yang dapat mengarah pada financial distress. Hancurnya perusahaan raksasa di dunia seperti kasus skandal perusahaan World.Com, Enron Corp., dan Global Crossing adalah suatu bentuk praktek kecurangan dalam pelaporan keuangan yang melibatkan akuntan publik (auditor eksternal) dalam manipulasi laporan keuangan yang mengakibatkan kebangkrutan dan ribuan karyawan kehilangan pekerjaan serta kerugian harga pasar milyaran dollar. Dari kasus tersebut juga berdampak menurunnya kepercayaan publik dan investor terhadap informasi keuangan dan juga profesi akuntan seluruh dunia (Law, 2011).

Praktik manipulasi dalam laporan keuangan Perseroan kadang melibatkan auditor eksternal (akuntan publik). Tidak hanya kasus yang terjadi di luar negeri, kasus tersebut juga banyak terjadi di Indonesia. Baru-baru ini, kasus manipulasi laporan keuangan terjadi pada perusahaan multipembiayaan yaitu PT.Sunprima Nusantara Pembiayaan (SNP) salah satu anak usaha dari Columbia Group yang merugikan 14 Bank hingga triliunan rupiah (Hukum Online.Com, 2018). Atas kasus ini, OJK memberikan sanksi administratif kepada KAP Satrio Bing Eny \& Rekan beserta dua akuntan publiknya (liputan6.com).

Salah satu upaya yang dapat dilakukan perusahaan untuk mencegah terjadinya kecurangan dalam penyajian laporan keuangan adalah dengan menerapkan sistem Corporate Governance. Penelitian Sutojo dan Aldridge (2005) menyatakan bahwa Badan Pengelola Pasar Modal di berbargai negara yang menerapkan tata kelola perusahaan (corporate governance) dengan baik di perusahaan publik, telah berhasil mencegah terjadi praktik kecurangan penyajian laporan keuangan. Untuk itu, corporate governance sangat berperan sebagai alat kontrol dalam upaya pencegahan dan mengurangi tindakan kecurangan pada pelaporan keuangan yang melibatkan manajemen. Dari penelitian yang dilakukan oleh Arief W dan M. Syafruddin (2017) menjelaskan bahwa struktur corporate governance terbukti dapat dijadikan kontrol bagi pemegang saham dalam mengurangi kecurangan dalam pelaporan keuangan yang dilakukan oleh pihak manajemen.

Dengan adanya beberapa fenomena atau peristiwa yang telah terjadi mengenai kecurangan dalam pelaporan keuangan, sangat menarik untuk diteliti karena dampak kerugian akan kecurangan tersebut cukup berpengaruh bagi pengguna laporan keuangan. Keterbaharuan dari penelitian ini adalah menambahkan variabel komisaris independen, sedangkan penelitian yang dilakukan oleh Arief Widodo dan M. Syafruddin (2017) tidak ada variabel komisaris independen. Sehingga tujuan dari penelitian adalah untuk menguji pengaruh pengungkapan corporate governance yang meliputi jumlah dewan komisaris (BOC), komposisi komisaris independen (BOC_IND), komite audit (AC), audit internal (IA) dan keberadaan KAP big four terhadap indikasi kecurangan dalam pelaporan keuangan pada perusahaan sektor non keuangan yang terdaftar di Bursa Efek Indonesia.

\section{TINJAUAN PUSTAKA}

\section{Good Corporate Governance}

Berdasarkan SK Menteri No.23/MPM/BUMN/2000, Good Corporate Governance merupakan instrument yang berbeda dari corporate management, karena GCG secara konsptual adalah system yang mengatur dan mengendalikan perusahaan yang menciptakan nilai tambahn untuk semua stakeholder dengan menekankan dua hal yaitu perusahaan wajib untuk melakukan pengungkapan secara akurat, tepat waktu dan transparan terhadap semua informasi kinerja perusahaan dan hak pemegang saham untuk memperoleh informasi dengan benar.

Berdasarkan definisi di atas, Corporate Governance merupakan suatu upaya perusahaan agar dapat menjalankan usahanya secara baik dengan memperhatikan hak dan kewajiban bagi semua pihak yang berkepentingan. Menurut Kusumawardhani (2012) Mekanisme tata kelola perusahaan dapat diproksikan dengan komposisi dewan komisaris, dewan direksi, dan komite audit.

1. Dewan Komisaris

Dewan Komisaris merupakan salah satu organ Perseroan yang bertugas melakukan pengawasan atas kebijakan perusahaan, serta memberikan pengarahan kepada Direksi untuk menjalankan Perseroan guna mencapai visi dan 
misi perusahaan. Pelaksanaan rapat Dewan Komisaris diadakan setiap 2 (dua) bulan sekali merujuk pada Peraturan OJK No.33/POJK.04/2014. Rapat Dewan Komisaris dapat pula atau merupakan rapat gabungan dengan GCG yang lain sepertu Direksi atau Komite-Komite.

2. Komisaris Independen

Dalam menetapkan strategi perusahaan bersama-sama Dewan Komisaris lainnya, Komisaris Independen harus memberi perlindungan hak pemegang saham serta mengawasi Direksi dan operasi keuangan perusahaan. Komisaris Independen harus mampu dan cakap dalam meninjau materi Transaksi dengan pihak berelasi secara signifikan sehingga dapat menunjukkan apakah Komisaris Independen berpihak pada kepentingan terbaik bagi perusahaan dan pemegang saham secara adil.

Komisaris independen dapat memberikan kontribusi keputusan penting perusahaan yang cukup subtantif, terutama dalam mengevaluasi kinerja eksekutif, pengaturan remunerasi eksekutif dan komisaris, meninjau laporan keuangan, dan dalam menyelesaikan konflik korporasi.

3. Komite Audit

Pembentukan Komite Audit pada Perseroan ditujukan untuk membantu Dewan Komisaris dalam pelaksanaan fungsi pengawasan sesuai dengan penerapan Good Corporate Governance atas hal-hal yang terkait dengan informasi keuangan, pengendalian internal, pengelolaan risiko serta kepatuhan terhadap peraturan perundangan yang berlaku. Persyaratan menjadi anggota Komite Audit antara lain memiliki integritas, memahami bisnis perusahaan, laporan keuangan, proses audit dan peraturan perundangan.

4. Audit Internal

Audit internal berfungsi untuk mengoptimalkan pengelolaan manajemen resiko dan penerapan praktik-praktik tata kelola perusahaan yang baik dan menjaga kepatuhan setiap unit kerja terhadap standar operasi, peraturan dan system pengendalian internal sesuai dengan pedoman yang telah ditetapkan Perseroan. Audit internal bertanggung jawab untuk memastikan efektivitas pencapaian tujuan Perseroan melalui pelaksanaan audit dan evaluai terhadap proses pengendalian kegiatan operasional, serta tata kelola perseroan dan memberikan keyakinan atas kecukupan pengendalian internal untuk meningkatkan kegiatan operasional Perseroan.

5. KAP Big Four

Audit eksternal memainkan peran utama dalam pengawasan keuangan perusahaan dan pemerintah karena mereka dilakukan oleh seseorang yang independen yang berkerja di Kantor Akuntan Publik (KAP) dan memiliki tanggung jawab untuk memberikan opini laporan keuangan client yang sesuai dengan Standar Akuntansi Keuangan (SAK).

Di Indonesia kita mengenal 4 Kantor Akuntan Publik terbesar, antara lain (1) Pricewaterhouse Coopers $(\mathrm{PwC}), \quad$ yang merupakan penggabungan usaha antara Price Waterhouse dan Coopers \& Lybrand, (2) Deloitte Touche Tohmatsu merupakan gabungan nama William Welch Deloitte, George Touche, dan Panglima Nobuzo Tohmatsu, (3) Ernst \& Young (EY) di Indonesia berafiliasi dengan Kantor Akuntan Publik Purwantono, Suherman \& Surja dan (4) KPMG (Klynveld, Piet, Marwick \& Goerdeler) di Indonesia dengan partner lokal dari KAP Siddharta \& Widjaja.

\section{Fraud (Kecurangan)}

Fraud atau kecurangan adalah suatu tindakan yang melanggar aturan atau prosedur yang dengan sengaja memanipulasi atau merekeyasa untuk memperoleh suatu keuntungan pribadi atau organisasi sehingga menimbulkan kerugian bagi pihak lain. Menurut Arens et.al. (2009), kecurangan dalam pelaporan keuangan adalah salah saji pelaporan, penghilangan jumlah atau pengungkapan yang dengan sengaja kepada penggunanya.

\section{Perumusan Hipotesis}

Terjadinya suatu tindakan kecurangan yang tidak dapat terdeteksi oleh auditor dapat memberikan dampak yang tidak bagus pada pelaporan keuangan dan merugikan para pihak baik stakeholder maupun investor. Manajemen bertanggung jawab untuk menerapkan tata kelola perusahaan (corporate governance) dan prosedur kontrol untuk meminimalkan risiko kecurangan, yang dapat dikurangi melalui kombinasi langkahlangkah pencegahan, pencegahan dan deteksi.

Melalui penerapan Corporate Governance, diharapkan dapat mengurangi suatu tindakan kecurangan (fraud) yang terjadi di dalam perusahaan atau dapat dicegah sejak awal. Untuk membantu manajemen dan dewan direksi dalam upaya anti fraud, AICPA bersama dengan beberapa organisasi profesional, mengeluarkan Management 
Programs and Controls: panduan untuk membantu mencegah, pencegahan dan mendeteksi kecurangan.

\section{Pengaruh Dewan komisaris (BOC) terhadap Indikasi Fraud dalam Pelaporan Keuangan.}

Pada dasarnya, tugas dan wewenang Komisaris adalah mengawasi pengurusan Perseroan yang dilakukan oleh Direksi dan memberikan nasihat kepada Direksi. Komisaris juga membuat rekomendasi saran perbaikan atas hasil penelaahan kinerja perusahaan. Berdasarkan Anggaran Dasar Perseroan, dewan komisaris di tunjuk dan diberhentikan oleh (RUPS) Rapat Umum Pemegang Saham. Berdasarkan POJK No. 33/POJK.04/2014 tanggal 8 Desember 2018 pasal 20, Dewan Komisaris paling kurang terdiri dari 2 (dua) orang anggota, yaitu 1 (satu) di antaranya adalah komisaris independen.

Menurut Nasution dan Setiawan (2007) menjelaskan bahwa dewan komisaris dibentuk untuk diberikan tugas dan tanggung jawab dalam mengawasi kualitas informasi pada pelaporan keuangan. Tugas pengawasan ini dilakukan untuk mencegah dan mengurangi kecenderungan kecurangan yang terdapat pada laporan keuangan dan memastikan bahwa perusahaan telah melaksanakan corporate governance dengan baik.

Abbot et al (2000) dalam Razali dan Arshad (2014), mengemukakan bahwa ukuran dewan komisaris memiliki hubungan yang signifikan dengan pemantauan kualitas pelaporan keuangan sehingga dapat mencegah kemungkinan terjadinya kecurangan dalam pelaporan keuangan. Dari pernyataan tersebut, hipotesis yang dapat dirumuskan adalah sebagai berikut:

$\mathrm{H}_{1}$ : Dewan komisaris (BOC) berpengaruh positif terhadap indikasi fraud dalam pelaporan keuangan.

\section{Pengaruh Komposisi Komisaris Independen terhadap Indikasi Fraud dalam Pelaporan Keuangan.}

Komisaris independen, secara umum merupakan bagian dari dewan komisaris atau dengan kata lain dewan komisaris juga merangkap sebagai komisaris independen. Jumlah komisaris independen beranggotakan sedikitnya 30\% (tiga puluh persen) dari komposisi Dewan Komisaris Perseroan. Sebagai komisaris independen, walaupun tidak terlibat dalam kegiatan operasional perusahaan tetapi mereka bertindak secara independen untuk mengawasi kegiatan operasional Perseroan demi kepentingan antara principal dan agent. Dari hasil penelitian oleh Murhadi (2009) yang menunjukan bahwa komisaris independen tidak memilik pengaruh terhadap kemungkinan kecurangan dalam pelaporan keuangan. Penelitian yang telah dilakukan oleh Murhadi (2009) tidak sejalan dengan landasan teori yang ada, untuk itu, penulis ingin merumuskan hipotesis sebagai berikut:

$\mathrm{H}_{2}$ : Komisaris independen (BOC_IND) berpengaruh positif terhadap indikasi fraud dalam pelaporan keuangan.

\section{Pengaruh Komite Audit terhadap Indikasi Fraud dalam Pelaporan Keuangan.}

Pembentukan Komite Audit di Perseroan ditunjuk untuk membantu Dewan Komisaris untuk melaksanakan fungsi pengawasan atau hal-hal yang terkait dengan informasi keuangan. Dalam praktiknya Komite Audit bertindak secara independen namun juga dapat berkoordinasi dengan Unit Audit Internal untuk melakukan review dan diskusi pembahasan terkait kinerja Perseroan guna mendorong terciptanya mekanisme pengawasan yang lebih baik, lebih koordinasi, sekaligus meningkatkan kualitas keterbukaan informasi dalam pelaporan keuangan. Bapepam (2004) mensyaratkan jumlah komite audit sedikitnya 3 (tiga) orang, diketuai oleh dewan komisaris independen perusahaan dan dua orang dari eskternal yang independen.

Pada penelitian yang dilakukan oleh Gregious dan Anis (2015), menunjukan bahwa efektifitas komite audit berpengaruh dalam mengurangi kecurangan pelaporan keuangan. Hasil penelitian tersebut sejalan dengan hasil penelitian Razali dan Arshad (2014). Berdasarkan pernyataan tersebut, hipotesis yang dapat dirumuskan adalah sebagai berikut:

$\mathrm{H}_{3}$ : Komite Audit (IA) berpengaruh positif terhadap indikasi fraud dalam pelaporan keuangan.

\section{Pengaruh Audit Internal terhadap Indikasi Fraud dalam Pelaporan Keuangan.}

Pedoman tata kelola perusahaan yang baik mensyaratkan perlunya pengendalian internal dalam rangka menjaga kekayaan dan kinerja perushaan serta memenuhi peraturan perundangundangan. Menurut Bapepam-LK No. IX.I.7, menyatakan bahwa Emiten dan Perusahaan Publik wajib membentuk Unit Audit Internal yang menjalankan fungsi audit internal yaitu, memberikan keyakinan dan konsultasi yang bersifat independen dan objektif dengan tujuan untuk meningkatkan nilai dan memperbaiki operasional perusahaan, melalui pendekatan yang sistematis, 
dengan cara mengevaluasi dan meningkatkan pengendalian dan proses tata kelola perusahaan (GCG). (Harden, 2010).

Dari beberapa literatur sebelumnya seperti Law (2011), Alleyne dan Howard (2005), mengemukakan bahwa Perseroan yang memiliki audit internal yang efektif cenderung memiliki indikasi kecurangan lebih sedikit. Dari uraian tersebut, maka hipotesis penelitian dirumuskan sebagai berikut:

$\mathrm{H}_{4}$ : Audit internal (IA) berpengaruh positif terhadap indikasi fraud dalam pelaporan keuangan.

\section{Pengaruh Keberadaan KAP big four terhadap Indikasi Fraud dalam Pelaporan Keuangan.}

Auditor eksternal adalah orang yang bekerja pada Kantor Akuntan Publik yang memiliki tugas pokok memeriksa laporan keuangan sesuai dengan standar audit yang ditetapkan oleh IAPI. Standar tersebut mengharuskan akuntan public untuk melaksanakan audit untuk memperoleh keyakinan memadai bahwa laporan keuangan bebas dari salah saji material.

Kualitas audit dapat dilihat dari kompetensi auditor dan juga dari sikap independen auditor (Ahadiat, 2011). Penelitian kualitas audit difokuskan bagi Perseroan yang di audit oleh perusahaan audit ternama terutama berafilasi asing dan perusahaan audit kecil atau lokal, dengan alasan jika perusahaan audit yang berafiliasi asing memiliki kemampuan untuk mendeteksi dan mengungkapkan laporan manajemen yang terdapat penyimpangan (Watts dan Zimmerman, 1981), dan jika terjadi kegagalan selama proses pemeriksaan maka perusahaan audit tersebut juga akan mendapatkan kerugian (Bauwhede et al., 2003) yaitu reputasi dan kompetensi atau kemampuan auditor menjadi diragukan oleh publik. Dari penelitian Krishnan (2003), mengemukakan bahwa perusahaan audit yang besar yang di ikuti dengan kualitas audit yang tinggi dapat membatasi praktik manajemen laba. Untuk itu hipotesis penelitian yang diajukan adalah:

$\mathrm{H}_{5}$ : KAP Big Four berpengaruh positif terhadap indikasi fraud dalam pelaporan keuangan.

\section{Kerangka Pemikiran}

Berikut ini adalah kerangka pemikiran dalam penelitian ini :
Gambar 2.1

Kerangka Pemikiran

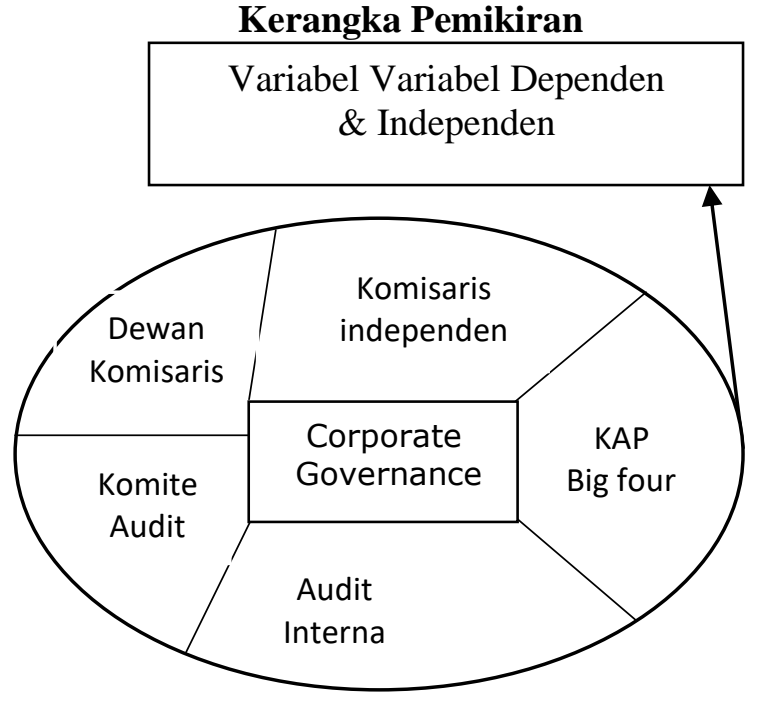

\section{METODELOGI PENELITIAN}

\section{Desain Penelitian}

Desain penelitian ini menggunakan analisis statistik deskriptif dengan metode kuantitatif. Data yang digunakan pada penelitian berupa data sekunder yang berasal dari laporan keuangan tahunan Perseroan pada Sektor Keuangan non Bank yang terdiri dari sub sektor asuransi, lembaga pembiayaan, sekuritas (efek) dan sektor keuangan lainnya yang terdaftar di Bursa Efek Indonesia. Alat statistik dan pengujian yang digunakan adalah uji statistik deskriptif, uji regresi logistik dan uji hipotesis.

\section{Populasi dan Tehnik Pengambilan Sampel}

Populasi yang akan menjadi objek penelitian adalah perusahaan sektor keuangan non bank yang diperoleh dari website Bursa Efek Indonesia www.idx.co.id mulai tahun 2016 sampai tahun 2018 sebanyak 47 perusahaan.

Pada penelitian ini teknik pengambilan sampel dengan purposive sampling, dimana jumlah sampel yang dipilih berdasarkan kriteria tertentu. Kriteria dalam menentukan sampel adalah perusahaan sektor keuangan non bank yang mempublikasikan laporan keuangan tahunan pada tahun 2016 sampai dengan tahun 2018 sebanyak 36 perusahaan. Sehingga total data yang dijadikan sampel penelitian sebanyak 108 perusahaan.

\section{Operasional dan Pengukuran Variabel}

Pada tabel 3.1 berikut ini adalah operasional dan pengukuran variabel penelitian: 
Tabel 3.1

Operasional Variabel Penelitian

\begin{tabular}{|c|c|c|c|}
\hline Variabel & Indikator & Pengukuran & Skala \\
\hline $\begin{array}{l}\text { Variabel } \\
\text { Independen }\end{array}$ & & & \\
\hline \multirow[t]{5}{*}{$\begin{array}{l}\text { Corporate } \\
\text { Governance: }\end{array}$} & $\begin{array}{ll}\text { a. } & \text { Dewan } \\
& \text { komisaris }\end{array}$ & $\begin{array}{l}\text { Total jumlah } \\
\text { dewan } \\
\text { komisaris }\end{array}$ & Rasio \\
\hline & $\begin{array}{ll}\text { b. } & \text { Komisaris } \\
& \text { Independen }\end{array}$ & $\begin{array}{l}\text { Jumlah } \\
\text { anggota } \\
\text { komisaris } \\
\text { independen / } \\
\text { Jumlah total } \\
\text { Dewan } \\
\text { Komisaris }\end{array}$ & Rasio \\
\hline & $\begin{array}{ll}\text { c. Komite } \\
\text { Audit }\end{array}$ & $\begin{array}{l}\text { - Indeks 1: } \\
\text { seluruh } \\
\text { item } \\
\text { diungkapk } \\
\text { an } \\
\text { - Indeks } 2 \text { : } \\
\text { item yg } \\
\text { diungkapk } \\
\text { an tidak } \\
\text { sesuai } \\
\text { pedoman } \\
\text { CG } \\
\text { - Indeks } 3: \\
\text { jika item } \\
\text { tidak } \\
\text { diungkapk } \\
\text { an }\end{array}$ & Ordinal \\
\hline & 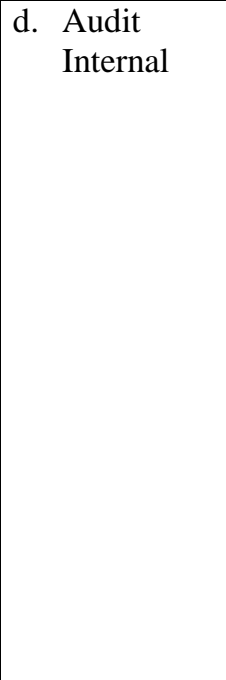 & $\begin{array}{l}\text { - Indeks 1: } \\
\text { seluruh } \\
\text { item } \\
\text { diungkapk } \\
\text { an } \\
\text { - Indeks } 2 \text { : } \\
\text { item yg } \\
\text { diungkapk } \\
\text { an tidak } \\
\text { sesuai } \\
\text { pedoman } \\
\text { CG } \\
\text { - Indeks } 3 \text { : } \\
\text { jika item } \\
\text { tidak } \\
\text { diungkapk } \\
\text { an }\end{array}$ & Ordinal \\
\hline & $\begin{array}{ll}\text { e. } & \text { KAP Big } \\
& \text { Four }\end{array}$ & $\begin{array}{l}\text { - Angka 1: } \\
\text { Perusahaa } \\
\text { n yg di } \\
\text { audit oleh } \\
\text { KAP big } 4 \\
\text { - Angka 0 : } \\
\text { Perusahaa } \\
\text { n yg tidak } \\
\text { di audit } \\
\text { oleh KAP } \\
\text { big } 4\end{array}$ & Ordinal \\
\hline
\end{tabular}

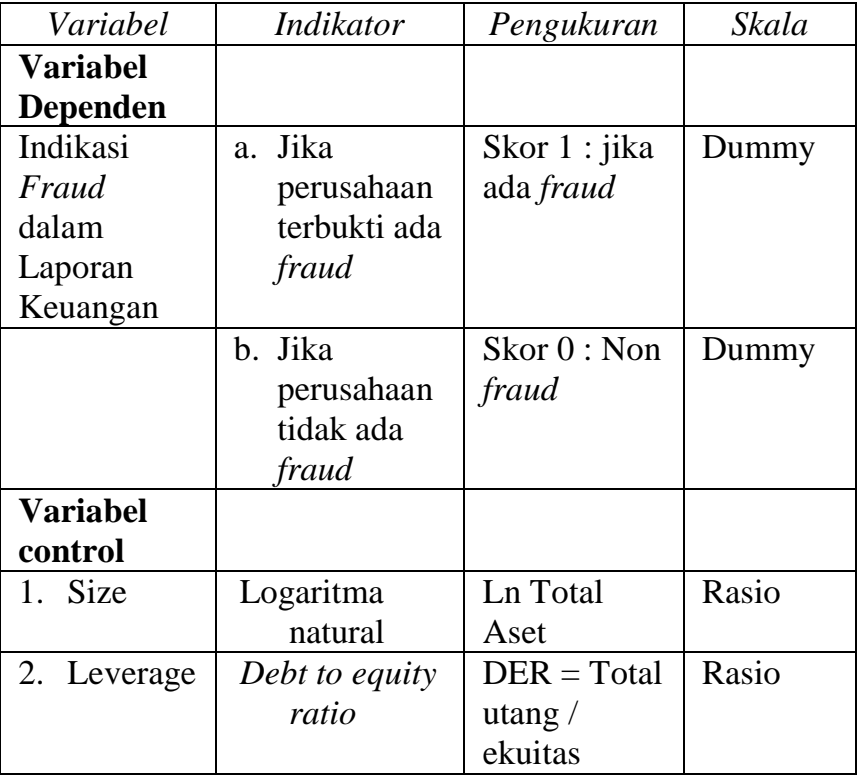

Sumber : Arief W. dan M. Syafruddin (2017)

\section{Teknik Pengumpulan Data}

Teknik pengumpulan data penelitian ada berbagai macam seperti pengamatan (observation), dokumentasi (documentation), wawancara (interview) dan juga gabungan (Sugiyono, 2016). Dalam hal ini penulis melakukan teknik pengambilan data menggunakan library research (kepustakaan) untuk memperoleh data sekunder. Data sekunder di dapat melalui www.idx.co.id yang meliputi data laporan keuangan tahunan pada Sektor Keuangan Non Bank dan referensi dari jurnal ilmiah maupun buku untuk mencari pembahasan yang sesuai dengan judul yang penulis kaji.

\section{Metode Analisis Data}

Metode analisis data menggunakan analisis regresi logistic, untuk menguji pengaruh pengungkapan corporate governance terhadap indikasi fraud dalam pelaporan keuangan, persamaan model regresi logistik yang dibentuk yaitu:

Fraud $=\beta 0+\beta 1$ BOC + $\beta 2$ BOC_IND + $\beta 3$ AC +
$\beta 4$ AI $+\beta 5$ KAP_BIG4 + $\beta 6$ SIZE $+\beta 7$ LEV + e

Keterangan:

Fraud = Variabel dummy, kode 1 untuk perusahaan yang melakukan fraud, kode 0 untuk perusahaan non fraud.

$\beta 0=$ Konstanta

$\beta 1-\beta 7=$ Koefisien regresi masing-masing variabel

BOC = jumlah anggota dewan komisaris

BOC_IND $=$ jumlah anggota komisaris independen

AC $=$ komite audit 
IA $\quad=$ audit internal

KAP_BIG4 $=$ keberadaan KAP big four

SIZE $=$ ukuran perusahaan

$\mathrm{LEV} \quad=$ leverage

e $=$ error

Menurut Diany \& Ratmono (2014), dalam melakukan analisis regresi logistik, dilakukan pengujian Kelayakan Model Regresi, dan Pengujian Simultan.

1. Menguji Kelayakan Model Regresi

Penilaian untuk mengujian kelayakan model regresi logistik menggunakan Hosmer and Lemeshow's Goodness of Fit Test Goodness yang diukur dari nilai Chi-square dengan kriteria sebagai berikut :

- Jika hasil perhitungan menunjukan nilai sig. $<0.05$, artinya antara model dengan nilai observasinya terdapat perbedaan signifikan sehingga nilai Goodness of Fit Test dikatakan tidak baik, karena model tidak dapat memprediksi nilai observasinya.

- Jika hasil perhitungan menunjukan nilai sig. $>0.05$, artinya antara model dengan nilai observasinya tidak ada perbedaan signifikan sehingga nilai Goodness of Fit Test dikatakan baik, karena model dapat memprediksi nilai observasinya.

2. Pengujian Simultan (Omnibus Test of Model Coefficient)

Pengujian simultan dilakukan dengan cara membandingkan antara nilai probabilitas (sig.) < tingkat signifikansi $(\alpha) 5 \%$, artinya secara keseluruhan model fit dengan data.

3. Uji Hipotesis (Variables in the equations)

Pengujian hipotesis dilakukan dengan melihat nilai probabilitas (sig.) < tingkat signifikansi $(\alpha)$ 0,05 yang berarti hipotesis pada variabel bebas berpengaruh terhadap variabel terikat. Dan apabila nilai probabilitas (sig.) > tingkat signifikansi $(\alpha)$ 0,05 maka hipotesis pada variabel bebas tidak berpengaruh terhadap variabel terikat.

\section{HASIL DAN PEMBAHASAN}

\section{Karakteristik Sampel Penelitian}

Berdasarkan kriteria pengambilan sampel pada perusahaan keuangan non bank yang terdaftar di Bursa Efek Indonesia dari tahun 2016 - 2018 (3 tahun) berjumlah 36 perusahaan, sehingga total data penelitian yang digunakan sebanyak 108 perusahaan.
Tabel 4.1

Karakteritik Sampel Penelitian

\begin{tabular}{|c|l|c|}
\hline No. & $\begin{array}{l}\text { Perusahaan Keuangan non } \\
\text { bank }\end{array}$ & Jumlah \\
\hline 1 & $\begin{array}{l}\text { Total perusahaan yang } \\
\text { terdaftar di BEI }\end{array}$ & 47 \\
\hline 2 & $\begin{array}{l}\text { Laporan tahunan yang tidak } \\
\text { dipublikasikan di BEI }\end{array}$ & $(11)$ \\
\hline 3 & $\begin{array}{l}\text { Laporan tahunan yang dapat } \\
\text { digunakan (no.2 - no.3) }\end{array}$ & 36 \\
\hline 4 & $\begin{array}{l}\text { Periode penelitian tahun } \\
\text { 2016 - 2018 }\end{array}$ & 3 \\
\hline 5 & $\begin{array}{l}\text { Data penelitian yang } \\
\text { digunakan (no.4 x 3 tahun) }\end{array}$ \\
\hline
\end{tabular}

Sumber: data diolah

\section{Analisis Data}

Berdasarkan data perusahaan pada sektor keuangan non bank yang terdaftar di Bursa Efek Indonesia yang memiliki indikasi fraud (kecurangan) adalah sebagai berikut:

Tabel 4.2

Data Perusahaan yang Melakukan Fraud dan Non Fraud

\begin{tabular}{lccc}
\hline $\begin{array}{l}\text { Perusahaan Sektor } \\
\text { Keuangan Non Bank }\end{array}$ & Fraud & $\begin{array}{c}\text { Non } \\
\text { Fraud }\end{array}$ & Total \\
\hline Asuransi & 4 & 29 & 33 \\
Lembaga Pembiayaan & 25 & 11 & 36 \\
Sekuritas & 3 & 12 & 15 \\
Sektor lainnya & 2 & 22 & 24 \\
\hline Total & $\mathbf{3 4}$ & $\mathbf{7 4}$ & $\mathbf{1 0 8}$ \\
\hline
\end{tabular}

Sumber: data diolah, 2020

Dari data penelitian sebanyak 108 perusahaan, diperoleh hasil perusahaan sektor keuangan non bank yang melakukan fraud berjumlah 34 perusahaan, yang terdiri dari 4 perusahaan di sektor asuransi, 25 perusahaan pada sektor lembaga pembiayaan, untuk perusahaan sekuritas sebanyak 3 dan di sektor lainnya sebanyak 2 perusahaan. Sedangkan bagi perusahaan yang tidak ada indikasi kecurangan (non fraud) sebanyak 74 perusahaan, yang terdiri dari 29 perusahaan di sektor asuransi, 21 perusahaan di sektor lembaga pembiayaan, 12 perusahaan di sektor sekuritas dan untuk sektor lainnya sebanyak 22 perusahaan. Adapun kasus kecurangan yang terjadi pada perusahaan asuransi misalnya adanya tuntutan klaim atas polis (item yang tidak tercover), pembayaran premi dan lain sebagainya. Sedangkan untuk fraud pada perusahaan sektor lembaga pembiayaan lebih banyak misalnya yang terjadi pada PT. Adira Dinamika Multi Finance Tbk. (ADMF) selama tahun 2016 sampai tahun 2018 
mempunyai kasus kecurangan paling banyak yakni ada 191 kasus di tahun 2016 yang dilakukan oleh karyawan tetap, 197 kasus di tahun 2017 dan 169 kasus di tahun 2018 dengan potensi kerugian perusahaan sekitar Rp. 16,44 miliar. Untuk kasus yang dihadapi oleh perusahaan sekuritas tidak begitu banyak, seperti yang terjadi pada PT. Minna Padi Investama Sekuritas Tbk, (PADI) di tahun 2018 yang sedang mengahadapi kasus sehubungan dengan kegiatan penjaminan emisi efek Perseroan pada PT. Cipaganti Citra Graha dan sudah di daftarkan di Kepaniteraan Pengadilan Negeri Jakarta Selatan. Dan untuk kasus pada sektor lainnya seperti yang di alami oleh Equity Development Investment Tbk. (GSMF) di tahun 2016 dan tahun 2017 yang menghadapi gugatan yang diproses di Pengadilan Negeri Jakarta Pusat, namun atas kasus ini tidak terlalu berpengaruh terhadap kondisi perusahaan.

Perusahaan sektor keuangan non bank yang menggunakan jasa Kantor Akuntan Publik, baik KAP big four, non big four dan KAP lokal dapat dilihat pada tabel berikut ini:

Tabel 4.3

Data Perusahaan yang Menggunakan KAP

\begin{tabular}{ccccc}
\hline & $\begin{array}{c}\text { KAP } \\
\text { Big } \\
\text { Four }\end{array}$ & $\begin{array}{c}\text { KAP } \\
\text { Non } \\
\text { Big } \\
\text { Four }\end{array}$ & $\begin{array}{c}\text { KAP } \\
\text { Lokal }\end{array}$ & Total \\
\hline Perusahaan & 35 & 61 & 12 & $\mathbf{1 0 8}$ \\
\hline \multicolumn{4}{r}{ Sumber : data diolah, 2020 }
\end{tabular}

Dari 108 perusahaan sektor keuangan non bank yang menggunakan jasa Kantor Akuntan Publik big four sebanyak 35, terdiri dari PWC, EY, dan Deloitte. Perusahaan yang menggunakan KAP non big four ada 61 perusahaan, terdiri dari BDO, PKF, RSM, Moore Stephens, Crowe, Parker Randall dan Baker Tilly. Sedangkan perusahaan yang menggunakan KAP lokal sebanyak 12, yang terdiri dari dbsd\&a, Asep Rahmansyah Mansyur \& Suharyono, Drs. Ferdinand \& Rekan, Kanaka Puradiredja \& Suhartono, dan Waryono \& Mennix.

\section{Analisis Statistik Deskriptif}

Analisis statistik deskriptif memberikan deskripsi atau gambaran pada data yang terdiri dari nilai minimum, maksimum, rata-rata (mean) dan standar deviasi. Pengolahan data menggunakan program SPSS versi 22 for windows. Berikut adalah hasil analisis statistic deskriptif :
Tabel 4.4

Hasil Analisis Statistik Deskriptif

\begin{tabular}{|c|c|c|c|c|c|}
\hline Variabel & $\mathbf{N}$ & $\begin{array}{l}\text { Mini } \\
\text { mum }\end{array}$ & $\begin{array}{c}\text { Maxim } \\
\text { um }\end{array}$ & Mean & $\begin{array}{c}\text { Std. } \\
\text { Deviati } \\
\text { on }\end{array}$ \\
\hline $\begin{array}{l}\text { Board of } \\
\text { Commission }\end{array}$ & 108 & 2,00 & 7,00 & 34,630 & 1,24874 \\
\hline $\begin{array}{l}\text { BOC_Indep } \\
\text { enden } \\
\text { Audit }\end{array}$ & 108 & 25 & 75 & 4569 & 0,13088 \\
\hline $\begin{array}{l}\text { Committee } \\
\text { Internal }\end{array}$ & 108 & 1,00 & 2,00 & 1,0278 & 0,16510 \\
\hline Audit & 108 & 1,00 & 3,00 & 1,0833 & 0,36494 \\
\hline KAP_BIG 4 & 108 & 0,00 & 1,00 & 0,3241 & 0,47021 \\
\hline Size & 108 & 10,88 & 18,43 & 14,8592 & 1,50104 \\
\hline Leverage & 108 & 0,01 & 15,50 & 2,1928 & 2,39449 \\
\hline $\begin{array}{l}\text { Fraud } \\
\text { Valid N } \\
\text { (listwise) }\end{array}$ & 108 & 0,00 & 1,00 & 0,3148 & 0,46661 \\
\hline
\end{tabular}

Sumber: data sekunder yang diolah, 2020

Berdasarkan hasil ouput pada tabel 4.4 di atas, menunjukan bahwa:

1. Dewan komisaris (BOC) memiliki hasil nilai minimum sebesar 2,00, nilai maksimum sebesar 7,00, untuk nilai rata-rata (mean) sebesar 34,630 dan 1,24874 untuk nilai standar deviasi.

2. Komisaris Independen (BOC_Independen) menunjukan nilai minimum sebesar 0,25 , untuk hasil nilai maksimum sebesar 0,75 , nilai rata-rata (mean) sebesar 0,4569 dan standar deviasi menunjukan nilai sebesar 0,13088 .

3. Komite audit menunjukan nilai minimum sebesar 1,00, untuk hasil nilai maksimum sebesar 2,00, nilai rata-rata (mean) sebesar 1,0278 dan 0,16510 untuk nilai standar deviasi.

4. Audit internal memiliki hasil nilai minimum sebesar 1,00, nilai maksimum sebesar 3,00, untuk nilai rata-rata (mean) sebesar 1,0833 dan standar deviasi menunjukan nilai sebesar 0,36494 .

5. KAP Big four menunjukan nilai minimum sebesar 0,00, untuk hasil nilai maksimum sebesar 1,00, nilai rata-rata (mean) sebesar 0,3241 dan 0,47021 untuk nilai standar deviasi.

6. Ukuran perusahaan (Size) memiliki hasil nilai minimum sebesar 10,88 , nilai maksimum sebesar 18,43, untuk nilai rata-rata (mean) sebesar 14,8592 dan standar deviasi menunjukan nilai sebesar 1,50104. 
berpengaruh signifikan dalam menguragi kecurangan pelaporan keuangan.

Dari hasil pengujian pada variabel Audit Internal (IA) diperoleh nilai signifikansi sebesar $0.999>\alpha 0,05$, yang berarti hipotesis ke empat $\left(\mathrm{H}_{4}\right)$ ditolak dan $\mathrm{H}_{0}$ diterima artinya audit internal tidak memiliki pengaruh signifikan terhadap indikasi fraud dalam pelaporan keuangan. Dari data $\operatorname{Exp}(\mathrm{B})$ sebesar 0,000 terlihat apabila terjadi peningkatan pengungkapan aktivitas audit internal, tetap tidak mampu menurunkan tingkat indikasi fraud. Hal ini bisa disebabkan karena tugas dari audit internal bersifat evaluasi terhadap operasional kegiatan usaha, yang mengakibatkan cenderung terlambatnya pencegahan indikasi fraud. Selain itu, faktor conflict of interest di internal juga mempengaruhi kualitas dari aktivitas audit internal. Hasil penelitian ini berbeda dengan penelitian Gregorius Satrio \& Anis Chariri (2015) yang mengemukakan bahwa efektivitas audit internal berpengaruh signifikan terhadap kemungkinan kecurangan dalam pelaporan keuangan.

Hasil pengujian regresi logistik pada variabel KAP big four diperoleh nilai siginifikansi sebesar $0.01<0.05$ dengan nilai $\operatorname{Exp}(\mathrm{B})$ sebesar 3,867, yang berarti hipotesis kelima $\left(\mathrm{H}_{5}\right)$ diterima dan $\mathrm{H}_{0}$ ditolak, artinya keberadaan KAP big four berpengaruh signifikan terhadap indikasi fraud dalam pelaporan keuangan. Karena variabel KAP big four berpengaruh positif, maka setiap kenaikan nilai variabel ini akan meningkatkan pengungkapan indikasi fraud sebesar 3,867 kali. Peranan Kantor Akuntan Publik yang lebih besar cenderung memiliki standard prosedur dan pengawasan yang lebih efektif dan detail dalam mendeteksi dan mengungkapkan pelaporan manajemen yang tidak benar. Hasil ini sesuai dengan penelitian dari Arief Widodo \& M. Syafruddin (2017) yang menunjukan hasil bahwa keberadaan KAP Big Four berpengaruh signifikan dalam mengurangi kecurangan dalam pelaporan keuangan.

\section{KESIMPULAN}

\section{Kesimpulan}

Dari hasil pengujian yang telah dilakukan, dapat disimpulkan bahwa dewan komisaris dan KAP big four memiliki pengaruh positif dan signifikan terhadap indikasi kecurangan (fraud) dalam pelaporan keuangan. Sedangkan untuk variabel komisaris independen memiliki pengaruh negatif dan signifikan terhadap indikasi fraud. Pada variabel komite audit dan audit internal tidak memiliki pengaruh terhadap indikasi kecurangan dalam pelaporan keuangan. Secara keseluruhan, dapat ditarik kesimpulkan bahwa corporate governance terbukti dapat dijadikan kontrol bagi pemegang saham dalam mengurangi kecurangan dalam pelaporan keuangan.

\section{Implikasi}

Dari hasil penelitian ini, mempunyai implikasi bagi Kantor Akuntan Publik dan juga auditor seperti turunnya kepercayaan pengguna laporan keuangan terhadap jasa audit KAP tersebut. Dan bagi perusahaan yang terdapat indikasi fraud, dapat berimplikasi pada penurunan harga saham serta kepercayaan investor.

\section{Saran}

Saran yang dapat diberikan bagi perusahaan adalah agar dapat menerapkan dan menjalankan dengan baik Corporate Governance untuk meminimalkan indikasi kecurangan. Bagi stakeholders dan shareholders untuk lebih dapat berhati-hati dalam menggunakan laporan keuangan perusahaan. Untuk Kantor Akuntan Publik dan auditor yang melakukan pemeriksaan, diharapkan dapat mematuhi kode etik akuntan publik dan sesuai dengan standar audit yang berlaku serta mengikuti pedoman pada Standar Akuntansi Keuangan dalam menyusun laporan keuangan.

\section{DAFTAR PUSTAKA}

Sumber dari Buku:

Amin Widjaja Tunggal. 2012. Audit Kecurangan dan Akuntansi Forensik. Jakarta: Harvarindo.

Arens, Alvin A., Elder, Randal J., Beasley, Mark S. 2009. Auditing and Assurance Services An Integrated Approach. Singapore: Prentice Hall.

Arens, Alvin A., Elder, Randal J., Beasley, Mark S. 2008. Auditing dan Jasa Assurance "Pendekatan Terintegrasi" edisi ke-12 Jilid 2. Jakarta: Penerbit Erlangga.

Faiz Zamzami, Ihda Arifin Faiz, Mukhlis. 2018. Audit Internal Konsep dan Praktik (Sesuai International Standards for the Professional Practice of Internal Auditing 2013). Yogyakarta: Gadjah Mada University Press.

Fitrawansyah. 2014. Fraud and auditing. Jakarta: Mitra Wacana Media.

Ghozali, Imam. 2011. Analisis Multivariate Lanjutan dengan Program SPSS. Semarang: Badan Penerbit Universitas Diponegoro. 
SPAP, Standar Audit Seksi 316. 2009. Pertimbangan atas Kecurangan dalam Audit Laporan Keuangan. Jakarta: IAPI.

Sugiyono. 2009. Metode Penelitian Bisnis. Bandung: Alfabeta.

Sutojo, Siswanto dan E. Jhon Aldridge. 2005. Good Corporate Governance. Jakarta: PT. Damar Mulia Pustaka.

The Indonesian Institute for Corporate Governance (IICG). 2000.

Undang-Undang Perseroan Terbatas Nomor 40 Tahun 2007 pasal 108.

Sumber dari Jurnal:

Abbot, L. J., Park, Y Y., dan Parker, S. 2000. The Effects of Audit Committee Activity and Independence on Corporate Fraud. Managerial Finance, Vol. 26, No. 11: 55-67.

Arief W dan M. Syafruddin. 2017. Pengaruh Pengungkapan Struktur Corporate Governance Terhadap Kecurangan Pelaporan Keuangan. Diponegoro Journal of Accounting Voloume 6, Nomor 4, tahun 2017, Hal 1-10. ISSN (Online): 2337-3806.

Diany, Y. A., \& Ratmono, D. 2014. Determinan kecurangan laporan keuangan: pengujian teori fraud triangle (doctoral dissertation). Fakultas Ekonomika dan Bisnis.

Gregorius S. W. dan Anis C. 2015. Mekanisme Corporate Governance dan Kemungkinan Kecurangan Dalam Pelaporan Keuangan. Diponegoro Journal of Accounting Volume 4, Nomor 4 tahun 2015. ISSN (Online) : 2337-3806.

Komite Nasional Kebijakan Governance (KNKG). 2006. Pedoman Umum Good Corporate Governance Indonesia.
Law, P. 2011. Corporate Governance and No Fraud Occurrence in Organizations Hong Kong Evidence. Managerial Auditing Journal, Vol. 26. No.26: 501-518.

Yarry S.L dan Surtikanti. 2019. Analisis FaktorFaktor Yang berpengaruh Terhadap Pencegahan Fraud di Dalam Proses Pengadaan Barang dan Jasa (studi empiris pada Direktorat Jenderal Pengelolaan Ruang Laut). Volume 1, Nomor 1, Maret 2019, pp 31-43. ISSN: 2654-4636, E-ISSN: 2656$758 \mathrm{X}$.

Sumber dari Internet:

Rul. 16 November 2015. Sejarah The Big Four KAP (Kantor Akuntan Publik) diakses tanggal 24 Desember 2019 dari https://nurulirmawati.wordpress.com/2015/1 1/16/sejarah-the-big-four-kapkantor-akuntanpublik/.

Hukum Online.Com. 15 November 2018. Keterlibatan Akuntan Publik dalam Manipulasi Laporan Keuangan. Diakses tanggal 24 Desember 2019 dari https://www.hukumonline.com/berita/baca/lt 5bed467ca1e5e/keterlibatan-akuntan-publikdalam-manipulasi-laporan-keuangan/

Liputan6.com. 2018. Begini Awal Mula Kasus SNP Finance yang Rugikan 14 Bank. Jakarta. Diakses tanggal 24 Desember 2019 dari https://www.liputan6.com/bisnis/read/36532 57/begini-awal-mula-kasus-snp-financeyang-rugikan-14-bank

Bursa Efek Indonesia. Laporan Keuangan Tahunan, Perusahaan Sektor Keuangan Non Bank tahun 2016 - 2018. diakses tanggal 28 Desember 2019 dari www.idx.co.id. 